Fikrah: Jurnal Ilmu Aqidah dan Studi Keagamaan

issn 2354-6174 eissn 2476-9649

Tersedia online di: journal.iainkudus.ac.id/index.php/fikrah

Volume 8 Nomor 2 2020, (243-254)

DOI: 10.21043/fikrah.v8i1. 8005

\title{
Kiai Sebagai Figur Toleransi Kearifan Lokal di Lasem
}

\author{
Afina Izzati \\ Institut Agama Islam Negeri, Kudus, Indonesia \\ afinaizzatil@gmail.com
}

\begin{abstract}
This article wants to portray the role of Kyai as inspiration for tolerance in Lasem Central Java, Indonesia. Inter-religious tolerance as Lasem peoples' local wisdom. This research focuses on a complete picture of the phenomenon being studied. The approach used is a case study by exploring community interactions in the research object. In-depth interviews were done to get the data. The result of this research shows that tolerance is an appreciation and respect between individuals or groups with different backgrounds. The role of a kyai to raise people's tolerance, exemplify attitudes, and words to become a role model for the peoples of Lasem. An unwritten rule in the form of tolerance which has become a reference for the community in life and has become local wisdom in Lasem.
\end{abstract}

Kata kunci: Local wisdom, kyai, tolerance, tasamuh, role model

\begin{abstract}
Abstrak
Artikel ini bertujuan untuk menjawab fenomena toleransi yang terjadi di Lasem, di mana tokoh agama (kiai) yang menjadi tonggak toleransi, serta sikap toleransi masyarakat di Lasem tumbuh menjadi kearifan lokal. Penelitian ini berjenis kualitatif yaitu dengan melihat kondisi obyek yang alamiah dan dilengkapi dengan hasil wawancara. Penelitian ini menitik beratkan pada gambaran yang lengkap tentang fenomena yang sedang diteliti. Pendekatan yang digunakan adalah studi kasus dengan mendalami interaksi masyarakat di obyek penelitian. Hasil dari riset ini adalah sikap toleransi merupakan penghargaan dan penghormatan antar individu atau kelompok yang berbeda latar belakang. Kenyataan toleransi yang terjadi di Lasem, tidak terlepas dari peran seorang kiai yang dapat memberikan teladan sikap dan tutur kata untuk dijadikan panutan masyarakat Lasem. Aturan tidak tertulis berupa sikap toleransi yang telah menjadi acuan masyarakat dalam tata kehidupan dan menjadi kearifal lokal di Lasem.
\end{abstract}

Kata kunci: Kearifan lokal, kiai, sikap toleransi, tasamuh, teladan 


\section{Pendahuluan}

Toleransi merupakan hal paling utama dalam menciptakan kerukunan beragama. Bentuk toleransi yang mampu menyatukan banyaknya perbedaan akan menghadirkan jiwa-jiwa yang baik hati untuk saling memahami. Toleransi dikenal secara luas sebagai suatu sikap atau perilaku manusia yang tidak menyimpang dari aturan, di mana seseorang menghargai atau menghormati setiap tindakan orang lain lakukan (Kadir, 2018, hal. 108). Toleransi terbentuk secara turun-temurun dan sudah mengakar di hati setiap individu. Tidak ada norma atau aturan secara tertulis, semua diyakini sebagai warisan leluhur dan bagian dari ajaran agama (Lestari, 2017, hal. 51).

Munculnya beberapa kasus intoleransi di negeri ini, seperti tidak pernah berhenti. Berbagai riset menujukkan banyaknya kasus-kasus intoleransi di negara-negara multikultural, seperti Indonesia. Banyak hal yang menjadi pemicu, selain perbedaan agama juga disebabkan dari permasalahan internal. Meskipun demikian, masing-masing memiliki cara untuk merawat nilai-nilai toleransi yang ada. Diantaranya dengan kesadaran akan semboyan negara, yaitu Bhineka Tunggal Ika (Mujtahidin, Mahmud, \& Nurtamam, 2017, hal. 127; Rahmanika et al., 2018, hal. 142). Selain itu memperkuat hubungan keluarga, saling menghormati, serta gotong royong merupakan sikap yang mampu mewujudkan toleransi di tengah kehidupan masyarakat majemuk (Rahmanika et al., 2018). Sedangkan sikap epoché turut dapat diciptakan dalam mewujudkan harmonisasi masyarakat multikultural, dengan memiliki sikap toleransi yang tinggi (Chasram, 2016, hal. 197).

Selain itu, ada metode yang dapat diterapkan melalui pemberian pengetahuan di dunia pendidikan. Pendidikan mengenai toleransi menjadi transmisi nilai-nilai yang ada di dalam al Quran, dengan harapan lahir generasi yang dapat menjunjung tinggi penghargaan atas perbedaan. Oleh karena itu pentingnya para tokoh untuk memberikan pembelajaran tentang nilai-nilai toleransi (Farihah, 2014, hal. 295-318; Lestari, 2017; Sugianto, 2019, hal. 112)

Artikel ini memfokuskan pada toleransi antarumat beragama di Lasem dengan melihat peranan sosok kiai sebagai penggerak nilai-nilai toleransi, yang kemudian menjelma menjadi kearifan lokal. Toleransi yang dibatasi pada sosok kiai sebagai penggeraknya, tidak terlepas dari pengaruh kiai atau tokoh agama di Lasem yang mampu memberikan dampak besar bagi masyarakat, mengingat kiai menjadi sentral figur bagi masyarakat. Sementara itu, pemilihan Lasem bagi penulis karena penerapan nilai-nilai toleransi sangat 
kuat di tengah masyarakat Lasem dengan berbagai latar belakang keagamaan, tetap dapat merawat sikap toleransi yang telah mengakar menjadi sebuah tradisi, yang pada akhirnya menjadi kearifan lokal.

\section{Metode}

Artikel ini menggunakan pendekatan kualitatif yang meneliti pada kondisi obyek yang alamiah tanpa sebuah eksperimen yang menitik beratkan pada gambaran yang lengkap tentang fenomena toleransi yang sudah menjadi kearifan lokal di Lasem. Lasem dipilih sebagai lokasi riset karena memiliki keberagaman budaya dan agama namun tetap mampu menjaga harmonisasi.

Pendekatan yang digunakan adalah studi kasus dengan memahami, menelaah, dan kemudian menafsirkan makna yang didapat dari fenomena yang diteliti, yaitu interaksi masyarakat di Lasem dalam kehidupan seharihari. Peneliti mengamati dan menganalisis mengapa dan bagaimana toleransi ini bisa menjadi sebuah kearifan lokal di Lasem.

Studi Kasus ini berupaya untuk menjelaskan dan menyimpulkan kejadian atau fenomena toleransi yang sudah menjadi kearifan lokal di Lasem. Objek pada artikel ini terbatas pada toleransi di tengah keberagaman di Lasem. Kiai sebagai figur toleransi dalam membangun potensi kearifan lokal di Lasem. Informan yang dipilih adalah masyarakat Lasem yang beragama Islam dan keturunan Cina dengan menamfaatkan metode pengambilan data berupa wawancara dan observasi.

\section{Pembahasan}

\section{Toleransi dan Perbedaan}

Toleransi merupakan suatu sikap saling menghargai dan menghormati antar individu atau kelompok di dalam masyarakat meskipun berbeda latar belakang. Toleransi sering dikaitkan dengan sikap lapang dada dan menunjukkan kesabaran (Hermawati, Paskarina, \& Runiawati, 2016). Jelas dapat dimengerti bahwa toleransi ini muncul karena munculnya perbedaan prinsip, dan penghormatan atas perbedaan prinsip orang lain tanpa mengorbankan prinsip sendiri (Montana, Loisa, \& Utami, 2019).

Toleransi adalah sikap saling menghormati dan menghargai yang muncul akibat sebuah perbedaan. Kehidupan toleransi sebagai wujud keharmonisasian yang ada di daerah Lasem dapat dijadikan cerminan terhadap 
kehidupan sosial di daerah lain yang memiliki latar belakang masyarakat yang beragam. Toleransi juga diartikan sebagai sikap untuk tidak mencampuri atau mengintervensi urusan atau perilaku pihak lain (Hermawati et al., 2016).

Pada umumnya toleransi diartikan sebagai pemberian kebebasan kepada sesama atau kepada semua warga masyarakat untuk menjalankan keyakinannya, mengatur hidup dan menentukan nasibnya masing-masing, selama dalam menjalankan dan menentukan sikapnya tidak bertentangan dengan syarat-syarat atas terciptanya ketertiban dan perdamaian dalam masyarakat. Sehingga toleransi sendiri merupakan prinsip untuk berperilaku lebih baik di masyarakat maupun terdapat perbedaan kepercayaan, selama pihak lain tidak secara langsung menghalangi kesejahteraan diri sendiri atau orang lain (Hayati \& Supena, 2019, hal. 247).

Anjuran toleransi secara teologis, di dalam Islam tidak akan pernah menghalangi toleransi atas nama agama. Namun, untuk memelihara kemurnian akidah tauhidiah dan syariah, Islam melarang keras perilaku toleransi yang mengarah kepada sinkretisme, kemurnian akidah tauhidiah dan syariah islamiah harus tetap dipertahankan (Ghazali, 2009). Toleransi dan menghormati eksistensi agama, tidak boleh dalam tindakan kesediaan mengikuti sebagian ajaran teologi ibadah agama lain. Mencampuradukkan satu agama dengan agama lainnya adalah perilaku kompromis-sinkretis, bukan bagian dari bentuk toleransi yang diperbolehkan (Muhammad, 2012).

Lahirnya toleransi dapat dipahami secara tidak langsung dengan adanya perbedaan-perbedaan yang muncul. Bagi masyarakat yang mau berpikir dan memahami perbedaan adalah sebuah anugerah dan rahmat yang diberikan Allah SWT kepada hambanya dengan maksud tertentu. Namun perbedaan juga dapat dijadikan sumber konflik bagi manusia yang tidak dapat mengambil pembelajaran dan hikmah dari perbedaan yang diciptakan oleh Tuhan. Sudah menjadi sunnatullah, jika setiap orang dibekali oleh Allah SWT dengan tingkat dan kemampuan akal yang berbeda, yang menyebabkan kapasitas keilmuan, ketajaman, dan arah analisis yang berbeda antara satu dengan lain. Maka perbedaan menjadi hal yang wajar terjadi bersamaan dengan relativitas akal manusia itu sendiri.

Islam tidak memungkiri adanya perbedaan, namun Islam hanya membenarkan perbedaan yang sifatnya tidak menentang prinsip-prinsip agama. Islam tetap mengingatkan untuk menghindari perbedaan yang sifatnya akan berakhir pada kecenderungan konflik dan melebih-lebihkan pembahasan 
yang tidak perlu dibahas. Di dalam al Quran Surat ar Rum ayat 31- 32 mengingatkan bahwa sebisa mungkin untuk umatnya menghindari perbedaan, yang menerangkan bahwa Allah tidak menyukai golongan yang memecah belah agamanya dengan membeda-bedakan golongan (Ghazali, 2009). Perbedaan dalam hakikat Islam adalah sebuah keniscayaan, Tuhan menciptakan setiap manusia dengan segala macam kelebihan dan kekurangan serta memiliki ciri khas yang berbeda-beda. Tuhan tidak mungkin menciptakan sesuatu yang sama, oleh karenanya perbedaan yang ada menjadi pelengkap satu sama lain.

Dengan adanya perbedaan, menunjukkan Allah SWT menghendaki setiap makhluknya untuk hidup saling tolong menolong dan membutuhkan satu sama lain. Itulah mengapa manusia dikatakan sebagai makhluk sosial. Karena keniscayaan bahwa manusia tidak akan pernah bisa hidup sendiri dengan keterbatasan yang dimilikinya masing-masing. keterbatasan yang dimiliki setiap manusia juga berbeda-beda satu dengan yang lainnya.

Allah menciptakan seluruh makhluknya berbeda-beda agar manusia saling mengenal dan merenungi makna indahnya perdamaian dalam perbedaan, sebagaimana dalam QS. al Hujurat ayat 13. Perbedaan bukan berarti pertentangan. karena sesuatu yang berbeda belum mesti berakibat buruk. Tergantung bagaimana setiap orang menyikapi perbedaan yang ada. Perbedaan yang Tuhan ciptakan tentu memiliki maksud dan tujuan tersendiri. Manusia sudah semestinya mensyukuri perbedaan yang telah Tuhan ciptakan dengan bijak menyikapi setiap perbedaan yang ada sebagai wujud syukur atas ciptaan Allah SWT (Ghazali, 2009).

Toleransi antarumat beragama dapat diwujudkan dalam bentuk diantaranya, saling menghormati antarumat beragama, memberi kebebasan kepada pemeluk agama lain dalam menjalankan ibadah sesuai dengan agama dan kepercayaannya masing-masing, tolong-menolong dalam berinteraksi sosial. Meskipun demikian antarumat beragama dapat diwujudkan sebagaimana tersebut di atas, tetapi bukan berarti dalam melaksanakan toleransi mencampur adukkan antara kepentingan sosial dan aqidah. Beberapa hal yang tidak dapat diterapkan dalam prinsip toleransi dalam Islam salah satunya adalah mengenai ibadah. Hal ini bersifat prinsip dan individual maksutnya menjadi urusan masing-masing tidak dapat dicampuri oleh agama dan kepercayaan lain. 


\section{Realitas Toleransi Di Lasem}

Lasem sendiri merupakan salah satu kecamatan terbesar di Kabupaten Rembang, memiliki 20 desa dan jumlah penduduk kurang lebih 47.868 jiwa pada tahun 2005. Lasem dikenal sebagai kota santri yang sudah menurunkan banyak ulama yang tersebar di Indonesia. Peninggalan pesantren-pesantren tua di kota ini dapat terekam jejaknya hingga sekarang.

Terdapat kurang lebih 19 (sembilan belas) pondok pesantren dalam satu kecamatan ini, di antaranya; al Wahdah (Sumbergirang), al Hidayat (Soditan), al Hidayat Putri (Soditan), at Taslim (Soditan), al Islah (Soditan), al Masudiy (Soditan), al Hamidiyah (Soditan), an Nur (Soditan), al Fakhriyyah (Sumbergirang), ash Sholatiyah (Sumbergirang), Nailun Najah (Sumbergirang), Kauman (Karangturi), al Hadi (Sumbergirang), al Muyassar (Sumbergirang), al Fatah (Ngemplak), Kutabbul Banat (Ngemplak), al Aziz (Ngemplak), Raudlatut Thulab (Ngemplak), Pondok Caruban (Gedongmulyo).

Lasem dikenal sebagai Tiongkok kecil karena merupakan kota awal pendaratan orang Tionghoa di tanah Jawa dan terdapat perkampungan Tionghoa. Hingga saat ini masih banyak keturunan Tionghoa yang tinggal dan berniaga di Lasem. Mereka hidup berdampingan dengan masyarakat muslim dan pesantren-pesantren yang ada disekelilingnya.

Toleransi agama dan sosial merupakan suatu kesatuan yang tidak dapat dipisahkan. Sikap saling menghargai antarumat beragama, menghormati keimanan setiap manusia tanpa mengganggu prosesi ibadah yang dilakukan. Sejatinya bagi kaum yang beragama memiliki sikap toleransi agama sebagai wujud keyakinan bahwa Allah SWT menciptakan makhluknya dengan berbedabeda.

Toleransi agama merupakan sikap positif yang harus dimiliki dalam rangka menciptakan kehidupan yang harmonis. Toleransi juga sebagai pangkal dari kerukunan sosial, tanpa adanya sikap saling toleransi maka tidak akan tercipta sikap saling menghormati, menyayangi dan saling mengasihi. Namun toleransi saat ini banyak di salah artikan. Hal ini karena wacana toleransi yang sering didiskusikan, ternayata tidak semua orang memahami hakikat toleransi beragama itu sendiri. Sebagian orang mengartikan bahwa wujud dari toleransi adalah mengikuti perayaan keagaan dari agama-agama lain. 
Islam telah mengenal toleransi sejak zaman Rasulullah Muhammad Saw. Adanya toleransi antarumat beragama, dalam Islam juga telah dijelaskan dalam al Quran dan al-Hadis. Keduanya merupakan pedoman hidup bagi umat Islam, yang berisikan petunjuk dari Allah SWT berupa larangan yang harus dihindari dan kewajiban yang harus dikerjakan oleh umat Islam. Sikap toleransi yang ditunjukkan oleh Rasulullah beserta para sahabatnya merupakan sikap yang terpuji, meskipun sikap tersebut terkadang tidak dihargai dengan baik oleh kaum non-Muslim tetapi mereka selalu menerimanya dengan lapang dada.

Istilah toleransi secara etimologi dari kata tolerance (dalam bahasa inggris) yang berarti sikap membiarkan, mengakui dan menghormati keyakinan orang lain tanpa memerlukan persetujuan. Dalam bahasa Arab dikenal dengan tasamuh, yang berarti saling mengizinkan, saling memudahkan (Munawar, 2007, hal. 16).

Perbedaan dan keberagamaan menyebabkan timbulnya berbagai kecenderungan: pertama, eklektisisme adalah suatu sikap keberagamaan yang berusaha memilih dan mempertemukan berbagai segi ajaran agama yang dipandang baik dan cocok untuk dirinya sehingga format akhir dari sebuah agama menjadi semacam mosaik yang bersifat eklektik (Moran, 2007, hal. 17). Eklektisme ini muncul salah satunya akibat kekecewaan terhadap salah satu agama atas ketidak mampuan menyelesaikan permasalahan agama, sehingga keberagaman muncul karena ketidak berdayaatn satu agama yang mencari kelebihan pada agama lain untuk dijadikan satu.

Kedua, sikap eksklusivisme melahirkan pandangan bahwa ajaran yang paling benar hanyalah ajaran agama sendiri, sedangkan agama lain sesat dan wajib dikikis, atau pemeluknya dikonversi, sebab agama dan penganutnya terkutuk dalam pandangan Tuhan (Hidayat, 2013, hal. 89).Sikap ini merupakan pandangan yang dominan dari zaman ke zaman, dan terus dianut hingga saat ini. Tuntutan kebenaran yang dipeluknya mempunyai ikatan langsung dengan tuntutan eksklusivitas. Artinya, kalau suatu pernyataan dinyatakan, maka pernyataan lain yang berlawanan tidak bisa benar. Sikap eksklusivisme ini menyebabkan timbulnya ekstrimisme dalam pandangan-pandangannya, sehingga sulit menerima kebenaran dari orang lain (Mujtahidin et al., 2017).

Ketiga, universalisme beranggapan bahwa pada dasarnya semua agama adalah satu dan sama. Hanya saja, karena faktor historis-antropologis, agama lalu tampil dalam format yang plural (Moran, 2007). Sikap universalisme ini 
menggap bahwa kebenaran itu bersifat menyeluruh, sehingga memiliki kepercayaan bahwa semua agama itu benar.

Kecenderungan-kecenderungan yang timbul di atas merupakan permasalahan yang timbul seiring munculnya perbedaan-perbedaan yang ada. Oleh karena itu diperlukan sikap toleransi dalam menangkal kecenderungankecenderungan perbedaan yang ada. Termasuk perbedaan yang ada di Lasem. Lasem menjadi salah satu daerah yang memiliki berbagai jenis latar belakang masyarakat, sehingga mengharuskan adanya kesatuan dan kerukunan antarumat. Toleransi menjadi jawaban dari usaha mewujudkan masyarakat yang bersatu dan rukun.

Munculnya kesadaran antarumat beragama yang diwujudkan dalam toleransi bisa menekan atau meminimalisasi konflik di masyarakat. Moto agree in disagreement yaitu toleransi beragama bukan hanya terjadi dalam kelompok beragama yang sama, tetapi juga dengan kelompok beragama yang berbeda dapat menjadi modal sosial yang kuat dalam toleransi beragama. Toleransi beragama yang dikembangkan bukan hanya menghargai teologi masingmasing agama dan umat beragama, tetapi juga memahami dan menghargai budaya dari umat beragama tersebut.

Relitas toleransi di Lasem terlihat dari interaksi sosial yang ada penuh kerukunan dan perdamaian. Banyak hal-hal yang dilakukan bersamaan meski berbeda latar belakang keagamaan. Seperti dalam sebuah moment pengobatan gratis yang pernah berada di pondok pesantren al Aziz Lasem yang justru diadakan oleh non muslim. Para tim dokter dari GKI (Gereja Kristen Indonesia) Lasem dan Surabaya. Selain itu banyak transaksi jual beli antar penjual dan pembeli yang berbeda kepercayaan. Banyak hal yang menggambarkan kerukunan umat beragama yang berada di Lasem.

Toleransi menjadi sikap dasar yang harus dimiliki oleh setiap masyarakat pluralis. Ini berarti bahwa toleransi harus di ajarkan oleh seseorang yang memberikan pengaruh besar dimasyarakat, sehingga sikap toleransi yang diajarkan dapat mudah diterima oleh masyarakat dari setiap golongan. Seseorang yang dapat memberikan pengaruh besar di masyarakat adalah kiai. Kiai merupakan tokoh masyarakat yang mengabdikan diri untuk kemaslahatan agama, baik melalui ucapan dan tindakan. Dalam rangka membangun kerukunan antarumat beragama, kiai dan para tokoh agama lain mampu memjadi figur yang pluralis (Farihah, 2014) 
Toleransi mengisyaratkan adanya sikap membiarkan dan tidak menyakiti sesama umat beragama, baik yang sejalan atau yang tidak. Toleransi tumbuh atas dasar kesadaran yang bebas. Namun toleransi dapat tumbuh dengan jalan perantara dari orang lain. Sikap toleransi dapat diajarkan oleh berbagai pihak yang memiliki pengarus besar di masyarakat.

Toleransi beragama yang dilakukan secara sadar akan menanggalkan sikap eksklusif antar masyarakat dan melahirkan sikap inklusif (Purnomo, 2003, hal. 35). Hal ini berarti mengaggap bahwa agama yang dianutnya adalah yang paling benar, namun tetap memberikan ruang kepada umat lain untuk menyatakan kebenaran pada agama yang dianutnya (Wekke, 2017).

\section{Potensi Kearifan Lokal}

Kearifan lokal merupakan cara orang bersikap dan bertindak dalam menanggapi perubahan lingkungan fisik dan budaya. Suatu gagasan konseptual yang hidup dalam masyarakat, tumbuh dan berkembang secara terus-menerus dalam kesadaran masyarakat dari yang sifatnya berkaitan dengan kehidupan yang sakral sampai dengan yang profan (Novia, 2016, hal. 5). Dapat dipahami bahwa kearifan lokal adalah sebagai gagasan-gagasan setempat (lokal) yang bersifat bijaksana, penuh kearifan, bernilai baik, yang tertanam dan diikuti oleh anggota masyarakatnya (Taufiq, 2018).

Haryanto menjelaskan bahwa bentuk-bentuk kearifan lokal adalah berupa kerukunan beragama dalam wujud praktik sosial yang dilandasi suatu kearifan dari budaya. Bentuk-bentuk kearifan lokal dalam masyarakat dapat berupa budaya (nilai, norma, etika, tata krama dalam keseharian, kepercayaan, adat istiadat, hukum adat, dan aturan-aturan khusus). Nilai-nilai luhur terkait kearifan lokal meliputi Cinta kepada Tuhan, alam semesta beserta isinya (Haryanto, 2014, hal. 212).

Kearifan lokal di Lasem berupa kekayaan budaya dan agama, erat kaitannya dengan sikap toleransi yang dimiliki masyarakat dan para tokoh agama. Kearifan lokal yang sudah terjadi menjadi potensi yang dapat dikembangkan melalui pemanfaatan sebagi salah satu kota wisata toleran. Hal ini didukung dengan banyaknya bangunan-bangunan yang berarsitektur budaya Cina dan budaya Islam. Seperti di masjid Jami' Lasem dan Pondok Pesantren Kauman, yang menggambarkan kehidupan berdampingan antarumat. Selain itu tampak dalam bidang perekonomian antarumat beragama. 
Kearifan lokal di Lasem ini telah diakui oleh banyak pihak, bahwa masyarakat Lasem hidup berdampingan bersama masyarakat dengan latar belakang yang beragam dan solidaritas yang dibangun secara turun temurun dengan mengutamakan sikap toleran antar masyarakat di Lasem yang terdiri dari masyarakat Islam santri, Islam Jawa (abangan), dan Masayarakat Cina (Tionghoa) (Geertz, 1992; Ritzer \& Douglas, 2009).

Toleransi yang dibangun masyarakat Lasem selama ini, merupakan budaya yang sudah dijaga dengan baik dan menjadi laten bagi masyarakat, sebagai perwujudan dari adaptasi antar pemeluk agama baik yang mayoritas maupun minoritas, ketika melakukan komunikasi baik dalam ruang-ruang dialog antar tokoh agama maupun para pengikutnya. Hal tersebut, merupakan tujuan dari hidup bersama dan berdampingan antarumat beragama agar harmonisasi dan keseimbangan dalam kehidupan bermasyarakat tetap terjaga dengan baik (Farihah \& Ismanto, 2019, hal. 15-17; Martono, 2016, hal. 57-58). Proses interaksi yang terjadi akan tetap dan selalu berlangsung, dan rasa tafahum dan tarahum antar mereka sudah menyatu tanpa dipaksakan (Abdullah, 2015, hal. 56). Oleh karena hidup berdampingan antarumat beragama sudah menjadi budaya lokal di masyarakat Lasem yang juga terlihat dari bentuk arsitektur yang ada di tengah masyarakat Lasem.

Riset ini berbeda dengan riset toleransi yang lain, yang sebelumnya lebih melihat pada sisi model toleransi yang sudah berjalan di masyarakat, sedangkan riset di Lasem bahwa toleransi antarumat beragam sudah menjadi budaya lokal masyarakat Lasem, meskipun keterbatasan dalam riset ini hanya pada wilayah Lasem, belum melihat pada wilayah pesisir di Kabupaten Rembang, yang dikenal sebagai wilayah santri, yang dapat dilihat dari banyaknya peantren di daerah pesisir.

\section{Simpulan}

Perbedaan yang muncul dalam kehidupan merupakan sunatullah yang tidak dapat dinafikan keberadaannya. Karena Tuhan menciptakan perbedaan untuk manusia agar manusia dapat saling menghargai. Dalam Islam sendiri, Allah SWT tidak menghendaki terjadinya permasalahan dan konflik dengan diciptakannya perbedaan. Itulah mengapa manusia harus berusaha menjaga kerukunan antarumat beragama. Kerukunan dapat terwujud dengan bersikap saling tepo sliro. 
Hidup berdampingan dengan meminimalisir terjadinya konflik dan mampu mewujudkan kehidupan yang seimbang di tengah perbedaan, maka toleransi menjadi salah satu solusinya. Hal tersebut tidak terlepas dari peranan kiai dan tokoh agama lainnya. Peran tokoh agama dan masyarakat memberikan motivasi kepada masyarakat untuk saling menghargai dan menghormati antarumat beragama di Lasem yang hidup di tengah perbedaan. Kiai sebagai tokoh agama memberikan motivasi melalui keteladanan sikap toleransi kepada sesama, yang dapat dijadikan panutan oleh masyarakat secara turun temurun.

\section{Referensi}

Abdullah, M. A. (2015). Sosiologi Dialog Antar Umat Beragama dalam Kemajemukan Negara-Bangsa. In Bunga Rampai sosiologi Agama: Teori, Metode dan Ranah Studi Ilmu Sosiologi Agama (hal. 107-113). Yogyakarta: Fakultas Ushuluddin dan Pemikiran Islam Universitas Islam Negeri Sunan Kalijaga.

Chasram. (2016). Membangun Sikap Toleransi Beragama dalam Masyarakat Plural. Wawasan: Jurnal Ilmiah Agama Dan Sosial Budaya.

Farihah, I. (2014). Strategi Dakwah di Tengah Konflik Masyarakat. Addin, 8(2), 295318.

Farihah, I., \& Ismanto, I. (2019). Buka Luwur as A Media of Education and Social Solidarity of Kudus Community. Al-Tahrir: Jurnal Pemikiran Islam, 19(1), 141159. https://doi.org/10.21154/altahrir.v19i1.1568

Geertz, C. (1992). Kebudayaan dan Agama. Yogyakarta.

Ghazali, A. M. (2009). Argumen Pluralisme Agama Membangun Toleransi Berbasis AlQur'an. Depok: Penyelian Aksara.

Haryanto, T. J. (2014). Kearifan Lokal Pendukung Kerukunan Beragama Pada Komunitas Tengger Malang Jatim. Jurnal Analisa (Online), 1(2).

Hayati, N., \& Supena, I. (2019). Pendidikan Toleransi Berbasis Etika Profetik. Fikrah: Jurnal Ilmu Aqidah Dan Studi Keagamaan.

Hermawati, R., Paskarina, C., \& Runiawati, N. (2016). Toleransi Antar Umat Beragama Di Bandung. Umbara: Indonesian Journal of Anthropology.

Hidayat, K. (2013). Menafsirkan Kehendak Tuhan. Bandung: Mizan.

Kadir, A. (2018). Merawat Kerukunan Toleransi di Era Demokrasi. Asketik.

Lestari, P. D. (2017). Toleransi dalam Keragaman: Studi Kasus Masyarakat Desa Gatak Jawa Tengah. Muasarah: Jurnal Kajian Islam Kontemporer.

Martono, N. (2016). Sosiologi Perubahan Sosial: Perspektif Klasik, Modern, Posmodern, dan Poskolonial. Jakarta: Rajawali Pers.

Montana, O., Loisa, R., \& Utami, L. S. S. (2019). Masyarakat dan Kearifan Budaya Lokal 
(Bentuk Pela Masyarakat di Negeri Batu Merah Kota Ambon Pasca Rekonsiliasi). Koneksi, 2(2), 507. https://doi.org/10.24912/kn.v2i2.3930

Moran, D. (2007). Introduction To Phenomenology. USA: Routladge.

Muhammad, N. H. (2012). Fiqh Sosial dan Toleransi Beragama. Kediri: Nasrul Ilmi.

Mujtahidin, Mahmud, \& Nurtamam, M. E. (2017). Peran Nilai Budaya dalam Membentuk Perspektif Toleran dan Intoleran di Madura: Studi Kasus Konflik Sunni-Syiah di Desa Karanggayam Kecamatan Omben Kabupaten Sampang Madura. Pamator, 10(2), 122-127.

Munawar, S. A. H. Al. (2007). Fikih Hubungan Antar Agama. Jakarta: Ciputat Press.

Novia, I. F. (2016). Pendidikan Karakter Berbasis Nilai-nilai Kearifan Lokal Adat Ammatoa Dalam Menumbuhkan Karakter Konservasi. Jurnal.

Purnomo, A. B. (2003). Membangun Teologi Inklusif-Pluralistik.

Rahmanika, K., Pratiwi, D. W., Santoso, A. P., HS, N. B., Susilowati, E., \& Yunarta, F. (2018). Toleransi Antar Umat beragama di kecamatan Prambanan Kabupaten Klaten. Fikri, 3(1), 119-142.

Ritzer, G., \& Douglas, J. (2009). Teori Sosiologi dari Teori Sosiologi Klasik sampai Perkembangan Mutakhir Teori Sosial Post-Modern. Yogyakarta: Kreasi Wacana.

Sugianto, E. (2019). Pendidikan Toleransi Beragama Bagi Genarasi Milenial. Misykat Al Anwar: Jurnal Kajian Islam dan Masyarakat.

Taufiq, T. T. (2018). Lingkungan dan Kearifan Lokal Masyarakat Muslim-Kristen Pesisir Banyutowo. Living Islam: Journal of Islamic Discourses, Vol. 1, hal. 341. https://doi.org/10.14421/lijid.v1i2.1264

Wekke, I. S. (2017). Harmoni Sosial Dalam Keberagaman Dan Keberagamaan Masyarakat Minoritas Muslim Papua Barat. KALAM, Vol. 10, hal. 295. https://doi.org/10.24042/klm.v10i2.3 